\title{
Construction of a novel cell-based assay for the evaluation of anti-EGFR drug efficacy against EGFR mutation
}

\author{
HIROTAKA HOSHI $^{1}$, GEN HIYAMA ${ }^{1}$, KOSUKE ISHIKAWA ${ }^{2}$, KIYOSHI INAGEDA ${ }^{1}$, JIRO FUJIMOTO ${ }^{2}$, \\ AI WAKAMATSU ${ }^{2}$, TAKUSHI TOGASHI ${ }^{2}$, YOSHIFUMI KAWAMURA ${ }^{2}$, NOBUHIKO TAKAHASHI $^{1}$, \\ ARISA HIGA $^{1}$, NAOKI GOSHIMA ${ }^{3}$, KENTARO SEMBA ${ }^{4}$, SHINYA WATANABE $^{1}$ and MOTOKI TAKAGI ${ }^{1}$ \\ ${ }^{1}$ Medical-Industrial Translational Research Center, Fukushima Medical University, Fukushima, Fukushima 960-1295; \\ ${ }^{2}$ Japan Biological Informatics Consortium (JBIC); ${ }^{3}$ National Institute of Advanced Industrial Science \\ and Technology (AIST), Koto-ku, Tokyo 135-0064; ${ }^{4}$ Department of Life Science and Medical Bioscience, \\ School of Advanced Science and Engineering, Waseda University, Shinjuku-ku, Tokyo 162-8480, Japan
}

Received June 13, 2016; Accepted October 17, 2016

DOI: 10.3892/or.2016.5227

\begin{abstract}
Epidermal growth factor receptor (EGFR) overexpression and EGFR-mediated signaling pathway dysregulation have been observed in tumors from patients with various cancers, especially non-small cell lung cancer. Thus, several anti-EGFR drugs have been developed for cancer therapy. For patients with known EGFR activating mutations (EGFR exon 19 in-frame deletions and exon 21 L858R substitution), treatment with an EGFR tyrosine kinase inhibitor (EGFR TKI; gefitinib, erlotinib or afatinib) represents standard first-line therapy. However, the clinical efficacy of these TKIs is ultimately limited by the development of acquired drug resistance such as by mutation of the gatekeeper T790 residue (T790M). To overcome this acquired drug resistance and develop novel anti-EGFR drugs, a cell-based assay system for EGFR TKI resistance mutant-selective inhibitors is required. We constructed a novel cell-based assay for the evaluation of EGFR TKI efficacy against EGFR mutation. To this end, we established non-tumorigenic immortalized breast epithelial cells that proliferate dependent on EGF (MCF 10A cells), which stably overexpress mutant EGFR. We found that the cells expressing EGFR containing the T790M mutation showed higher resistance against gefitinib, erlotinib and afatinib compared with cells expressing wild-type EGFR. In contrast, L858R mutant-expressing cells exhibited higher TKI sensitivity. The effect of T790M-selective inhibitors (osimertinib and rociletinib) on T790M mutant-expressing cells was significantly higher than gefitinib and erlotinib. Finally, when compared with commercially available isogenic MCF 10A
\end{abstract}

Correspondence to: Professor Motoki Takagi, Medical-Industrial Translational Research Center, Fukushima Medical University, 1 Hikariga-oka, Fukushima, Fukushima 960-1295, Japan

E-mail: m-takagi@fmu.ac.jp

Key words: epidermal growth factor receptor, EGFR tyrosine kinase inhibitor, EGFR mutation, T790M, molecular target drug, lung cancer, non-small cell lung cancer cell lines carrying introduced mutations in EGFR, our EGFR mutant-overexpressing cells exhibited obviously higher responsiveness to EGFR TKIs depending on the underlying mutations because of the higher levels of EGFR phosphorylation in the EGFR mutant-overexpressing cells than in the isogenic cell lines. In conclusion, we successfully developed a novel cell-based assay for evaluating the efficacy of anti-EGFR drugs against EGFR mutation.

\section{Introduction}

Epidermal growth factor receptor (EGFR) is a tyrosine kinase (TK) receptor that is activated by binding with ligands such as EGF and other growth factors. Activation of EGFR leads to the triggering of several downstream pathways including RAS/MAPK, PI3K/Akt and JAK/STAT pathways that regulate cell proliferation, survival, adhesion, migration, and differentiation (1). Overexpression of EGFR and dysregulation of EGFR-mediated signaling pathways have been observed in tumors from patients with various cancers, especially with non-small cell lung cancer (NSCLC), contributing to tumorigenesis and leading to a poor prognosis (2). Thus, EGFR is a promising molecular target as a therapeutic agent for patients with NSCLC and several anti-EGFR drugs have been developed for this purpose.

Lung cancer is the second most common cancer and remains the leading cause of cancer-related mortality worldwide. Notably, the majority of lung cancers (over $85 \%$ of patients) are categorized as NSCLC (3). Traditionally, lung cancer has been treated with surgery, radiation, and chemotherapy (4). Although chemotherapy has been the standard of care for patients with NSCLC, current clinical efforts are directed at molecular target drugs to improve outcome and reduce toxicity. Gefitinib, which primarily functions as an EGFR tyrosine kinase inhibitor (TKI), was approved in Japan for the treatment of NCLC in 2002 and in the USA in 2003. In 2004, the presence of somatic mutations in the TK domain of EGFR was identified in patients with NSCLC responding to gefitinib $(5,6)$. These mutations, consisting of in-frame deletions in EGFR exon 19 and the L858R substitution in exon 21, 
were associated with both in vitro sensitivity to gefitinib and therapeutic efficacy and are commonly referred to as 'activating mutations' as the mutant products are constitutively activated and oncogenic $(1,7)$. Together, these mutations constitute $80-90 \%$ of all EGFR mutations in NSCLC. In addition, mutations involving G719 and L861 are also associated with gefitinib sensitivity, but their incidence is much lower (7). Thus, for patients with known EGFR activating mutations, treatment with an EGFR TKI (gefitinib, erlotinib or afatinib) represents current standard first-line therapy $(8,9)$.

However, the clinical efficacy of gefitinib and erlotinib is ultimately limited by the development of acquired drug resistance such as by mutation of the gatekeeper T790 residue (T790M), which is the most frequent of acquired resistance mutations occurring in $\sim 60 \%$ of patients after treatment with EGFR TKIs $(1,7,9)$. Therefore, several EGFR TKIs have been developed for overcoming this acquired resistance to gefitinib and erlotinib. The so-called 'second-generation' of EGFR TKIs, which irreversibly and covalently bind with the catalytic site of the EGFR TK domain and widely inhibit TK receptors of the ErbB family (of which EGFR is a member), have been examined in clinical trials $(1,9)$. However, despite promising preclinical evidence of activity against EGFR-mutated cell lines harboring the T790M mutation (10-12), the second-generation inhibitors (afatinib, neratinib and dacomitinib) did not demonstrate significant activity in patients harboring the T790M mutation (13-15). Consequently, to overcome the limitations of the second-generation inhibitors, a novel class of mutant-selective 'third-generation' inhibitors has been developed. Among these, rociletinib $(16,17)$ and osimertinib (AZD9291) $(18,19)$, which irreversibly and covalently inhibit the T790M resistance mutation as well as the activating mutations (exon 19 deletions and L858R), showed activities against T790M-positive NSCLC in clinical trials.

An efficient cell-based assay system for the identification of clinically efficacious EGFR mutant-selective inhibitors is required. Although the cell-based assays with human EGFR-mutated cell lines have been already reported (20-22), the activity against currently utilized EGFR-mutated cell lines harboring the T790M mutation is inconsistent with activity of the agents in patients harboring the T790M mutation. In addition, although the assay systems with EGFR mutant-overexpressing murine cell lines for EGFR TKIs have been reported (23-25), the assay systems with a human cell line have been not reported yet. Thus, we have developed a novel cell-based assay with a human non-tumorigenic epithelial cell line for the evaluation of anti-EGFR drug efficacy against EGFR mutation. Wild-type, T790M mutant, and L858R mutant EGFR genes were introduced into human non-tumorigenic immortalized breast epithelial MCF 10A cells that exhibit EGF-dependent growth using a retrovirus system to effect overexpression. To predict the construct validity of our system, the activity of EGFR TKIs including first, second and third-generation agents was evaluated utilizing these EGFR mutant-expressing cells in comparison to currently utilized isogenic lines.

\section{Materials and methods}

Compounds. The 21 EGFR TKIs of the first, second and third-generation were used in this study (Table I). The stock solutions $(10 \mathrm{mM})$ of the compounds were prepared in dimethyl sulfoxide (DMSO) and stored at $-80^{\circ} \mathrm{C}$ until use. The stock solutions were arrayed in 384-well plates and serially diluted 3 times to yield a concentration range from $10 \mathrm{mM}$ to $52 \mathrm{nM}$. The purity and integrity of all compound solutions were measured using ultra performance liquid chromatographymass spectrometry (Waters, Milford, MA, USA) as follows: a Waters CORTECS C18 column $(1.6 \mu \mathrm{m}$, i.d. $2.1 \times 50 \mathrm{~mm})$ was developed with an aqueous acetonitrile containing a $0.1 \%$ formic acid linear gradient system (5-90\% MeCN, $1.6 \mathrm{~min}$; flow rate, $1 \mathrm{ml} / \mathrm{min}$ ), verifying the $\mathrm{UV}$ adsorption and mass of the major UV peaks (Table I).

Construction of retroviral plasmids containing the mutant genes. A wild-type EGFR cDNA clone was obtained from our human proteome expression resource library (HuPEX) (26). EGFR mutations were introduced into the wild-type cDNA using the QuickChange Lightning Multi Site-Directed Mutagenesis kit (Agilent Technologies, Santa Clara, CA, USA). pRetro-GW-IH, which was produced from pRetroX (Takara Bio, Shiga, Japan), was used as the retroviral vector. Wild-type and mutant EGFR constructs were transferred to the pRetro-GW-IH retroviral expression vector using the Gateway LR reaction (Thermo Fisher Scientific, Waltham, MA, USA).

Cell culture. MCF 10A cells were purchased from the American Type Culture Collection (ATCC, Manassas, VA, USA). The isogenic MCF 10A cell lines with EGFR mutations (L858R/+ and T790M/+) and their parental cells, used to create the mutant isogenic cells, were obtained from Horizon Discovery (Cambridge, UK). The GP2-293 packaging cell line was provided by Takara Bio.

MCF 10A cells were cultured in Dulbecco's modified Eagle's medium (DMEM)/Ham's F-12 (Wako, Tokyo, Japan) supplemented with $5 \%$ heat-inactivated horse serum (Gibco, Thermo Fisher Scientific), $10 \mu \mathrm{g} / \mathrm{ml}$ insulin (human, recombinant), $5 \mu \mathrm{M}$ forskolin (both from Wako), $0.5 \mu \mathrm{g} / \mathrm{ml}$ hydrocortisone (Sigma-Aldrich, St. Louis, MO, USA), 20 ng/ml EGF (human, recombinant), $100 \mathrm{U} / \mathrm{ml}$ penicillin, and $100 \mu \mathrm{g} / \mathrm{ml}$ streptomycin (all from Wako) at $37^{\circ} \mathrm{C}$ in a humidified incubator with $5 \% \mathrm{CO}_{2}$. GP2-293 packaging cells were cultured in DMEM (Wako) containing $10 \%$ heat-inactivated fetal bovine serum (Gibco) at $37^{\circ} \mathrm{C}$ in a humidified incubator with $5 \% \mathrm{CO}_{2}$. Cell number and viability were measured using trypan blue dye exclusion with a Vi-Cell counter (Beckman-Coulter, Brea, CA, USA). To estimate confluency and doubling time (DT), the cells were seeded in 96-well plates (cat. CLS3595; Corning Inc., Corning, NY, USA) at $5 \times 10^{3}$ cells/well and measured using an IncuCyte ZOOM live cell imaging system (Essen BioScience, Ann Arbor, MI, USA) and IncuCyte ZOOM software.

Retroviral packaging and infection. GP2-293 packaging cells were seeded into 6 -well plates at a density of $4 \times 10^{5}$ cells/well. The next day, the cells were transfected with $0.2 \mu \mathrm{g}$ plasmid containing the ecotropic envelope (env) gene and $2 \mu \mathrm{g}$ retroviral plasmid mixed with $7.2 \mu \mathrm{g}$ polyethylenimine (cat. 24765-2; Polysciences, Warrington, PA, USA). The culture supernatant was replaced with fresh medium at $7.5 \mathrm{~h}$ after transfection and again the following day. At $60 \mathrm{~h}$ after transfection, the 
Table I. EGFR TKIs used in this study.

\begin{tabular}{lllc}
\hline Compound & Generation & \multicolumn{1}{c}{ Supplier } & Purity (\%) \\
\cline { 2 - 3 } Erlotinib & First & Carbosynth & 100 \\
Gefitinib & First & Chemscene & 100 \\
AEE-788 & First & Active Biochem & 100 \\
AG-1478 & First & Selleck & 100 \\
Icotinib & First & Selleck & 100 \\
WHI-P154 & First & Selleck & 100 \\
PD 153035 & First & Selleck & 100 \\
Afatinib & Second & Selleck & 100 \\
Lapatinib & Second & LC Laboratories & 100 \\
AC 480 & Second & Selleck & 100 \\
Dacomitinib & Second & Selleck & 100 \\
Pelitinib & Second & Selleck & 100 \\
Varlitinib & Second & Selleck & 97.7 \\
AZD 8931 & Second & Selleck & 100 \\
AST-1306 & Second & Selleck & 95.2 \\
WZ3146 & Third & Selleck & 100 \\
WZ4002 & Third & Selleck & 100 \\
WZ8040 & Third & Selleck & 100 \\
Osimertinib & Third & MedChem & 100 \\
(AZD9291) & & & \\
Rociletinib & Third & MedChem & 100 \\
CUDC-101 & Multitarget & Selleck & 100 \\
\hline
\end{tabular}

${ }^{a}$ CUDC-101 also shows inhibition against histone deacetylase. EGFR, epidermal growth factor receptor; TKIs, tyrosine kinase inhibitor.

virus-containing culture supernatant was harvested and centrifuged at $1,000 \mathrm{x} \mathrm{g}$ for $5 \mathrm{~min}$ to remove cell debris. This was used as the virus solution.

MCF 10A cells (ATCC) expressing the ecotropic receptor gene were seeded into 6-well culture plates at a concentration of $7 \times 10^{5}$ cells and were infected with $1 \mathrm{ml}$ appropriately diluted virus solution containing $8 \mu \mathrm{g} / \mathrm{ml}$ hexadimethrine bromide (Sigma) the following day. At $24 \mathrm{~h}$ after infection, the cells were expanded onto a $10-\mathrm{cm}$ dish and cultured in medium containing $20 \mu \mathrm{g} / \mathrm{ml}$ hygromycin B (Wako).

Measurement of total and phosphorylated EGFR. Total and phosphorylated EGFR levels were detected by immunofluorescence staining. Cells were seeded at $4 \times 10^{3}$ cells/well onto 384-well bottom clear black plates (cat. 781096; Greiner Bio-One, Frickenhausen, Germany). After 24 h culture, the cells were fixed with $4 \%$ paraformaldehyde phosphate buffer solution (Wako). After blocking with $5 \%$ bovine serum albumin in Tris-buffered saline solution for $30 \mathrm{~min}$, the cells were incubated with primary antibodies against EGFR (mouse monoclonal clone AT2H8) and phospho-(Y1173)-EGFR (rabbit monoclonal clone E124) (both from Abcam, Cambridge, MA, USA) in 1:100 dilution at $37^{\circ} \mathrm{C}$ for $4 \mathrm{~h}$. The cells were then washed 3 times with Tris-buffered saline containing $0.05 \%$ Tween-20 solution followed by incubation with antimouse or anti-rabbit IgG antibodies conjugated to DyLight 488 or DyLigh594 (NovusBio, Littleton, CO, USA), respectively, in 1:1,000 dilution and stained with Hoechst 33342 solution (Dojindo Co., Kumamoto, Japan) in 1:1,000 dilution to visualize the nuclei at $37^{\circ} \mathrm{C}$ for $1 \mathrm{~h}$. The cells were imaged with a x10 objective and a fluorescein filter using the Operetta High Content Imaging system and analyzed with the Columbus Image Data Storage and Analysis system (both from PerkinElmer, Waltham, MA, USA) to identify the nucleus, EGFR and phospho-EGFR.

To test the inhibition of EGFR phosphorylation mediated by EGFR TKIs, the cells were seeded at $2 \times 10^{4}$ cells/well onto 96-well bottom clear black plates (cat. 6005182; PerkinElmer), cultured for $24 \mathrm{~h}$, and then treated with gefitinib, afatinib, or osimertinib for $1 \mathrm{~h}$. The cells were then fixed and stained as indicated above. The vehicle solvent (DMSO) was used as a control at a concentration of $0.1 \%$.

Growth inhibition assay. The growth inhibitory activity of EGFR TKIs against cells was assayed by measuring the amount of ATP in the cells using CellTiter-Glo (Promega, Madison, WI, USA). The cells were incubated in 384-well plates at a density of $1 \times 10^{3}$ cells/well with a medium volume of $40 \mu \mathrm{l}$ for $4 \mathrm{~h}$. The cells were then treated with $0.1 \mu \mathrm{l}$ EGFR TKI solutions at final concentration ranges of $25 \mu \mathrm{M}$ to $1.3 \mathrm{nM}$ (10-point dose) using an ADS-348-8 Multistage-dispense station (Biotec, Tokyo, Japan). The vehicle solvent (DMSO) was used as a control at a maximum concentration of $0.25 \%$. After 72 h, $10 \mu \mathrm{l}$ CellTiter-Glo reagent solution was added to the medium and the plate was mixed with a plate mixture and incubated for $10 \mathrm{~min}$ at $30^{\circ} \mathrm{C}$. The luminescence was measured using an EnSpire plate reader (PerkinElmer). The $\mathrm{IC}_{50}$ values were analyzed using Morphit software (The Edge Software Consultancy, Guildford, UK).

\section{Results}

Cells overexpressing EGFR mutant genes. To develop a cellbased assay system for evaluating EGFR TKIs, MCF 10A cells (ATCC), which are non-tumorigenic immortalized breast epithelial cells and EGF proliferation-dependent, were used in this study. Firstly, MCF 10A cells expressing ecotropic receptor were created and used as a control to establish MCF 10A cells overexpressing wild-type EGFR (WT) and EGFR mutants (L858R and T790M) using a retroviral system. The levels of total and phosphorylated EGFR (pY1173) were detected with immunofluorescence. As predicted, the mean intensities of green fluorescence corresponding to EGFR in the overexpressing cells were $\sim 1.5$ times higher than that of the MCF 10A cell line expressing the ecotropic receptor (Fig. 1A). The scattering in the EGFR expression histograms was narrow (SD, 195-451), suggesting that the amount of EGFR in the cells was constant. The levels of phosphorylated EGFR (red) in WT and T790M cells were $\sim 2$ times that of the control line, whereas the constitutively active EGFR mutant L858R showed a 3-fold increase compared with the control line (Fig. 1A). However, the scattering in the histograms of the phosphorylated EGFR levels in the gene-overexpressing cells was wide (SD, 1017-1707), suggesting that phosphorylated EGFR accumulated in the cells over time.

Next, we examined whether the depletion of EGF affected the proliferation of the various cells. The cells were cultured 
A
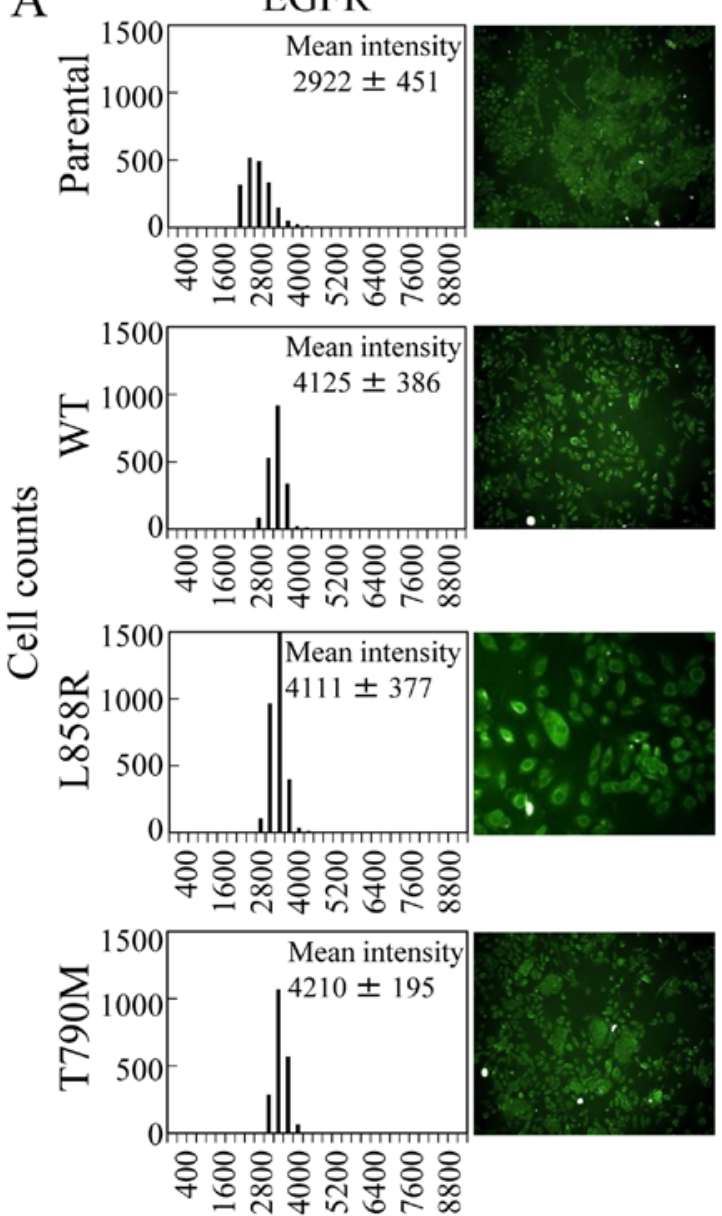

Fluorescence intensity

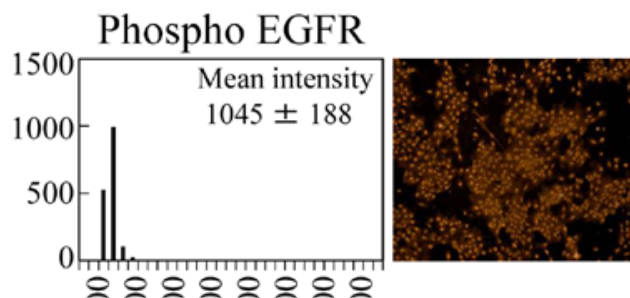

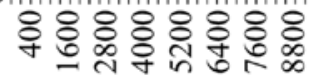

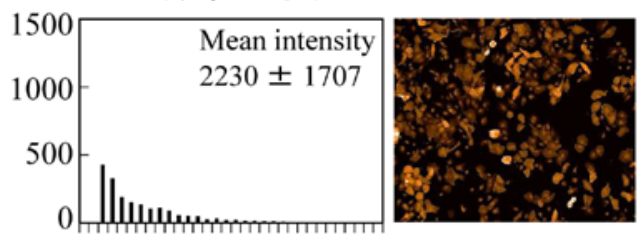

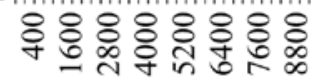

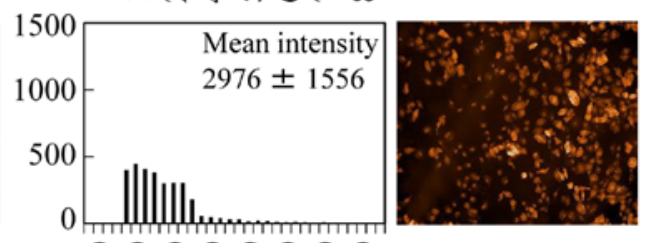

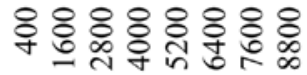

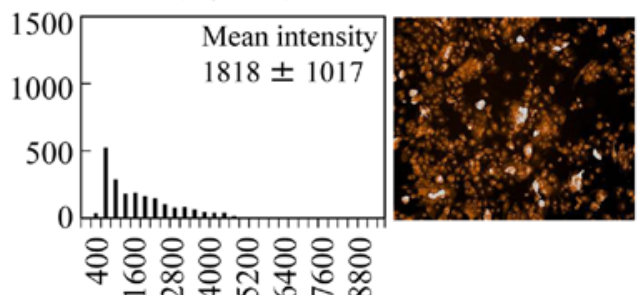

Fluorescence intensity

B : Presence of EGF O: Absence of EGF

Parental
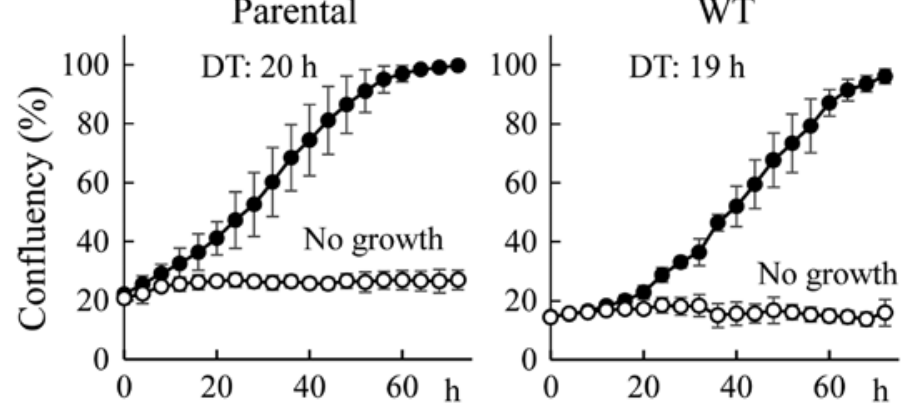

L858R
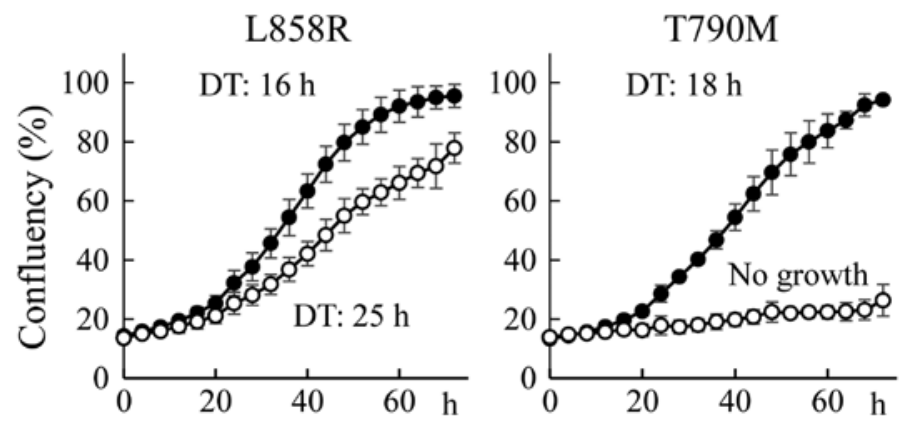

Figure 1. Evaluation of the control MCF 10A line and the cells overexpressing WT, L858R and T790M epidermal growth factor receptor (EGFR). (A) Levels of EGFR expression and its phosphorylation as measured using immunofluorescence. The fluorescence intensities of randomly selected 2,500 cells in 3 wells are shown as histograms in units of 400 . The data presented are the means \pm SD $(n=2,500)$. The fluorescence images using $x 10$ objective were electronically overlaid. (B) EGF dependency of cell growth in EGFR mutant-expressing cells. Cell images were captured with IncuCyte ZOOM live cell imaging system every $4 \mathrm{~h}$ and the doubling time (DT) of the cells was calculated. Each data point represents the means \pm SD ( $=9$ ) of three independent experiments. 

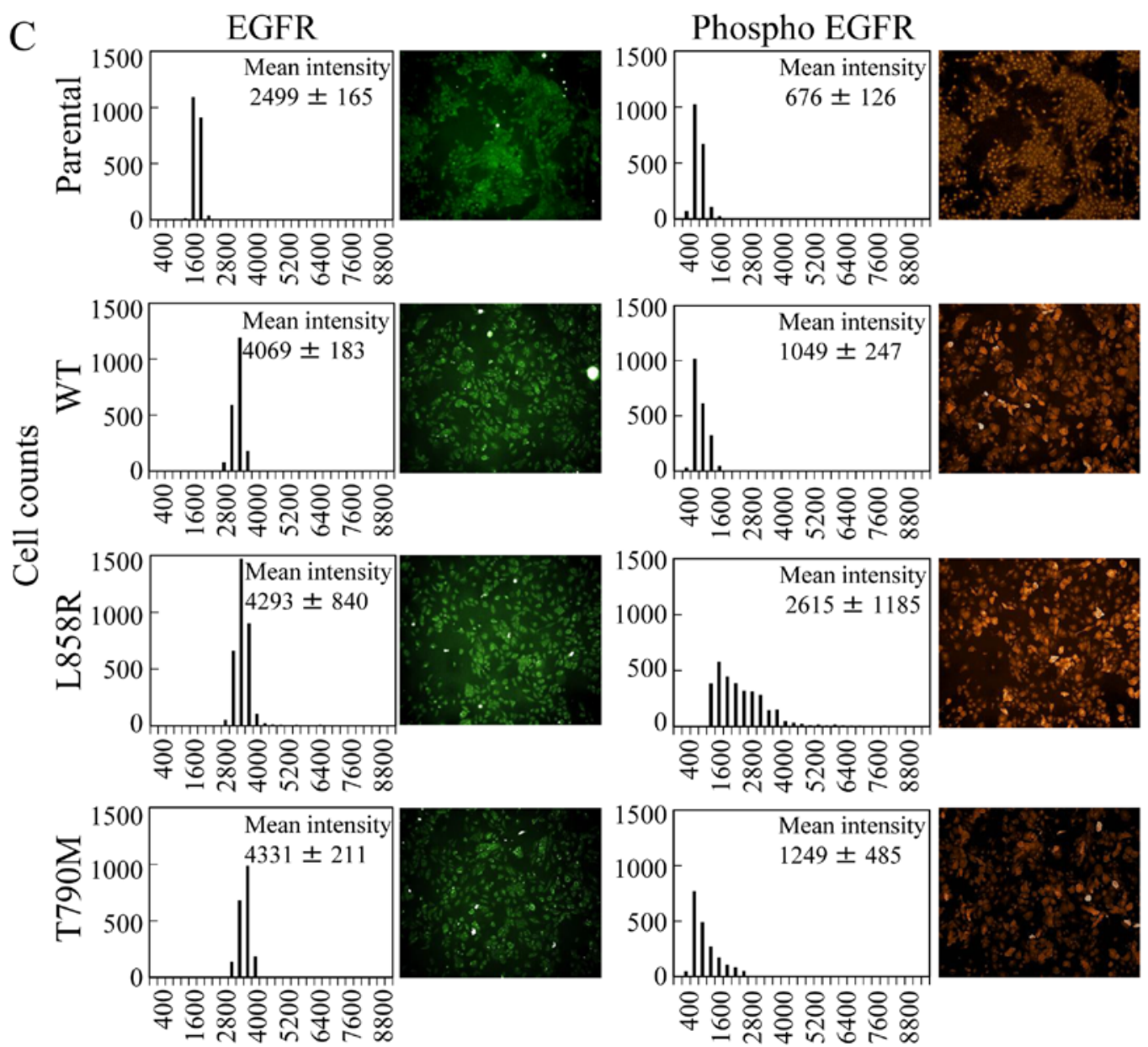

Fluorescence intensity

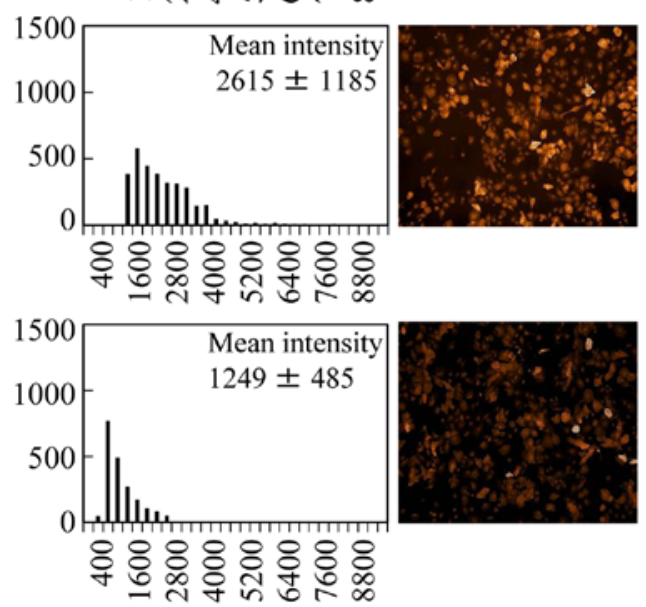

Fluorescence intensity

Figure 1. Continued. (C) Levels of EGFR expression and its phosphorylation in cells without EGF stimulation. The cells were cultured in 384-well plates. The medium was replaced with EGF-free medium at $24 \mathrm{~h}$ after seeding and the cells were cultured for $3 \mathrm{~h}$.

in medium with or without EGF for $72 \mathrm{~h}$. The confluency and DT of the cells were measured using the IncuCyte ZOOM live cell imaging system. DTs of WT, L858R, and T790M (16-19 h) cells were similar to the control line $(20 \mathrm{~h})$ in medium with EGF (Fig. 1B). In the absence of EGF, the control, WT and T790M lines did not grow, indicating that their growth is dependent on EGF (Fig. 1B). On the other hand, the constitutively active EGFR mutant L858R was able to proliferate in the absence of EGF; DTs of L858R with and without EGF were 16 and $25 \mathrm{~h}$, respectively.

To confirm the relationship between EGFR phosphorylation and EGF stimulation, the cells were cultured without EGF for $3 \mathrm{~h}$ and the phosphorylated receptor levels were measured (Fig. 1C). A high level of phosphorylated EGFR was found in the L858R overexpressing line that exhibits growth under these conditions of EGF depletion as was observed in culture with EGF, whereas the levels of phosphorylated EGFR of the other cells were low compared with the respective EGF-containing cultures (Fig. 1C).

Growth inhibitory effects of EGFR TKIs depend on the underlying EFGR mutation. To investigate the sensitivity of EGFR TKIs to L858R and T790M, a growth inhibitory assessment was conducted for the various cells treated with these agents. Each generation of EGFR TKIs under clinical use and in development was examined in these experiments (Table I). The cells were treated with the drugs at $4 \mathrm{~h}$ after seeding and incubated for $72 \mathrm{~h}$. Then, the numbers of viable cells were calculated by measuring the amounts of ATP in the cells using CellTiter-Glo reagents. The $\mathrm{IC}_{50}$ values of 21 EGFR TKIs against each cell type are shown in Table II. WT demonstrated greater resistance against all EGFR TKIs than the control cells. The $\mathrm{IC}_{50}$ values of the drugs against WT were $28 \mathrm{nM}-4.5 \mu \mathrm{M}$. Afatinib, which is a representative second-generation drug, exhibited the strongest inhibitory effect in 21 EGFR TKIs. No major difference was observed in the inhibitory effects between each generation of EGFR TKIs.

Next, the sensitivity of EGFR TKIs to L858R and T790M was evaluated. The relative ratios (mutant/WT) of the $\mathrm{IC}_{50}$ values of L858R and T790M were calculated (Table II). The $\mathrm{IC}_{50}$ values of all drugs against the constitutively active EGFR mutant L858R were significantly lower than those of the control and WT lines. In addition, these high sensitivities (ratios, 0.06-0.18) were especially evident in the first and third-generations of EGFR TKIs. On the other hand, T790M exhibited remarkable resistance against the first-generation agents. Although the relative ratios of the second-generation varied (1.68-104.58), a weaker inhibitory effect was observed 
Table II. IC $_{50}$ values of EGFR TKIs against control- and various EGFR-expressing cell lines.

\begin{tabular}{|c|c|c|c|c|c|}
\hline Compound & Generation & Control & WT & L858R & T790M \\
\hline Erlotinib & First & 0.221 & 0.379 & $0.031(0.08)$ & 4.315 (11.39) \\
\hline Gefitinib & First & 0.180 & 0.371 & $0.034(0.09)$ & $5.781(15.58)$ \\
\hline AEE-788 & First & 0.157 & 0.342 & $0.032(0.09)$ & $2.488(7.27)$ \\
\hline AG-1478 & First & 0.088 & 0.163 & $0.018(0.11)$ & $8.697(53.36)$ \\
\hline Icotinib & First & 0.524 & 0.601 & $0.043(0.07)$ & $14.639(24.36)$ \\
\hline WHI-P154 & First & 0.267 & 0.447 & $0.080(0.18)$ & $8.110(18.14)$ \\
\hline PD 153035 & First & 0.095 & 0.190 & $0.021(0.11)$ & $8.382(44.12)$ \\
\hline Afatinib & Second & 0.009 & 0.028 & $0.002(0.07)$ & $0.365(13.04)$ \\
\hline Lapatinib & Second & 1.612 & 4.502 & $2.590(0.58)$ & $7.564(1.68)$ \\
\hline AC 480 & Second & 1.159 & 1.637 & $1.452(0.89)$ & $10.274(6.28)$ \\
\hline Dacomitinib & Second & 0.011 & 0.037 & $0.002(0.05)$ & $1.060(28.65)$ \\
\hline Pelitinib & Second & 0.014 & 0.059 & $0.005(0.08)$ & $0.189(3.20)$ \\
\hline Varlitinib & Second & 1.550 & 2.483 & $1.217(0.49)$ & $8.331(3.36)$ \\
\hline AZD 8931 & Second & 0.013 & 0.040 & $0.004(0.10)$ & $4.183(104.58)$ \\
\hline AST-1306 & Second & 0.029 & 0.093 & $0.025(0.27)$ & $0.471(5.06)$ \\
\hline WZ3146 & Third & 0.114 & 0.309 & $0.028(0.09)$ & $0.156(0.50)$ \\
\hline WZ4002 & Third & 0.557 & 1.525 & $0.090(0.06)$ & $0.643(0.42)$ \\
\hline WZ8040 & Third & 0.096 & 0.285 & $0.016(0.06)$ & $0.102(0.36)$ \\
\hline Osimertinib & Third & 0.197 & 0.628 & $0.065(0.10)$ & $0.419(0.67)$ \\
\hline Rociletinib & Third & 0.754 & 1.667 & $0.246(0.15)$ & $0.778(0.47)$ \\
\hline CUDC-101 & Multitarget & 0.051 & 0.084 & $0.025(0.30)$ & $0.056(0.67)$ \\
\hline
\end{tabular}

$\mathrm{IC}_{50}$ values indicate $\mu \mathrm{M}$. The inhibitory ratio of mutant/WT $\mathrm{IC}_{50}$ values is shown in parentheses. EGFR, epidermal growth factor receptor; TKIs, tyrosine kinase inhibitor.

Table III. $\mathrm{IC}_{50}$ values of EGFR TKIs against the isogenic cells.

\begin{tabular}{llccc}
\hline Compound & Generation & Parental & L858R & T790M \\
\hline Erlotinib & First & 0.282 & $0.051(0.18)$ & $1.750(6.21)$ \\
Gefitinib & First & 0.218 & $0.045(0.21)$ & $0.846(3.88)$ \\
PD 153035 & First & 0.147 & $0.025(0.17)$ & $0.520(3.54)$ \\
WHI-P154 & First & 0.362 & $0.112(0.31)$ & $1.427(3.94)$ \\
Afatinib & Second & 0.016 & $0.002(0.13)$ & $0.017(1.06)$ \\
Lapatinib & Second & 2.085 & $2.330(1.12)$ & $4.823(2.31)$ \\
AC 480 & Second & 1.545 & $1.839(1.19)$ & $4.708(3.05)$ \\
Dacomitinib & Second & 0.023 & $0.003(0.13)$ & $0.031(1.35)$ \\
Osimertinib & Third & 0.323 & $0.084(0.26)$ & $0.301(0.93)$ \\
Rociletinib & Third & 1.167 & $0.303(0.26)$ & $0.504(0.43)$ \\
CUDC-101 & Multitarget & 0.066 & $0.038(0.58)$ & $0.078(1.18)$ \\
\hline
\end{tabular}

$\mathrm{IC}_{50}$ values indicate $\mu \mathrm{M}$. The inhibitory ratio of mutant/parental $\mathrm{IC}_{50}$ values is shown in parentheses. EGFR, epidermal growth factor receptor; TKIs, tyrosine kinase inhibitor.

against T790M than against the WT receptor. As expected, the inhibitory effect of the third-generation agents against T790M was the strongest compared to the first and second-generations.

Inhibition of EGFR phosphorylation with EGFR TKIs depends on the underlying EGFR mutation. Inhibition of
EGFR phosphorylation in WT, L858R and T790M by treatment with gefitinib, afatinib and osimertinib was analyzed by immunofluorescence. The cells were cultured on 96-well plates for $24 \mathrm{~h}$, treated with EGFR TKIs for $1 \mathrm{~h}$, fixed, and stained with the antibody against phosphorylated EGFR (pY1173). The inhibitory rates of EGFR phosphorylation in L858R markedly increased at low concentrations (3-30 nM) of gefitinib, afatinib and osimertinib compared with WT (Fig. 2). On the other hand, the levels of phosphorylated EGFR in T790M did not decrease at a high concentration ( $3 \mu \mathrm{M})$ of gefitinib or afatinib (Fig. 2), whereas a third-generation inhibitor, osimertinib, decreased the levels of phosphorylated EGFR in T790M to levels similar to WT (Fig. 2D). These results were identical to the growth inhibitory effects of these agents.

Comparison between the overexpressing and isogenic cells with EGFR mutations. To compare our mutant-expressing cells with the introduced mutant cells created by using isogenic cell line technology, we investigated the sensitivity of EGFR TKIs including each generation (Table III) toward the L858R and T790M mutant isogenic cells. First, we evaluated the levels of total and phosphorylated EGFR (pY1173) by immunofluorescence. The levels of total EGFR in the MCF 10A cell lines between two cell lines derived from ATCC and Horizon Discovery were different. The mean intensities of EGFR in the parental cells from Horizon Discovery (Fig. 3A) were $\sim 1.5$ times higher than those of the control cells from ATCC (Fig. 1A). The mean intensities and histograms of 

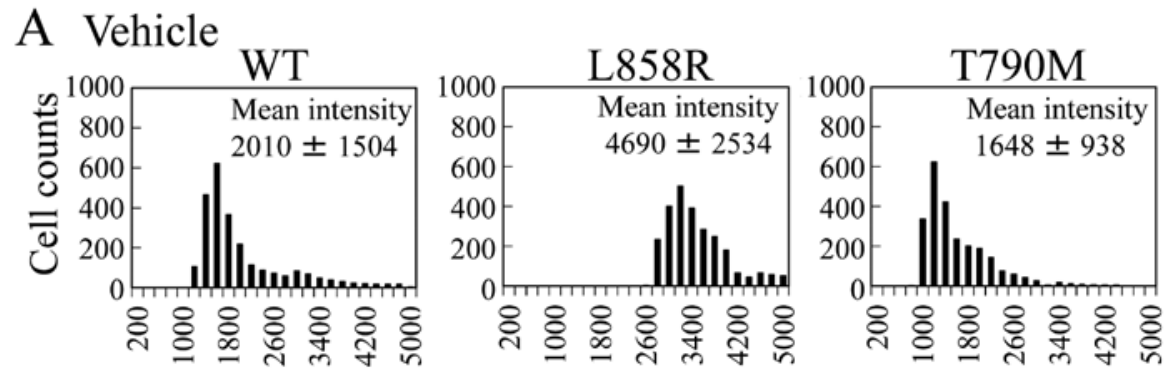

\section{Fluorescence intensity}
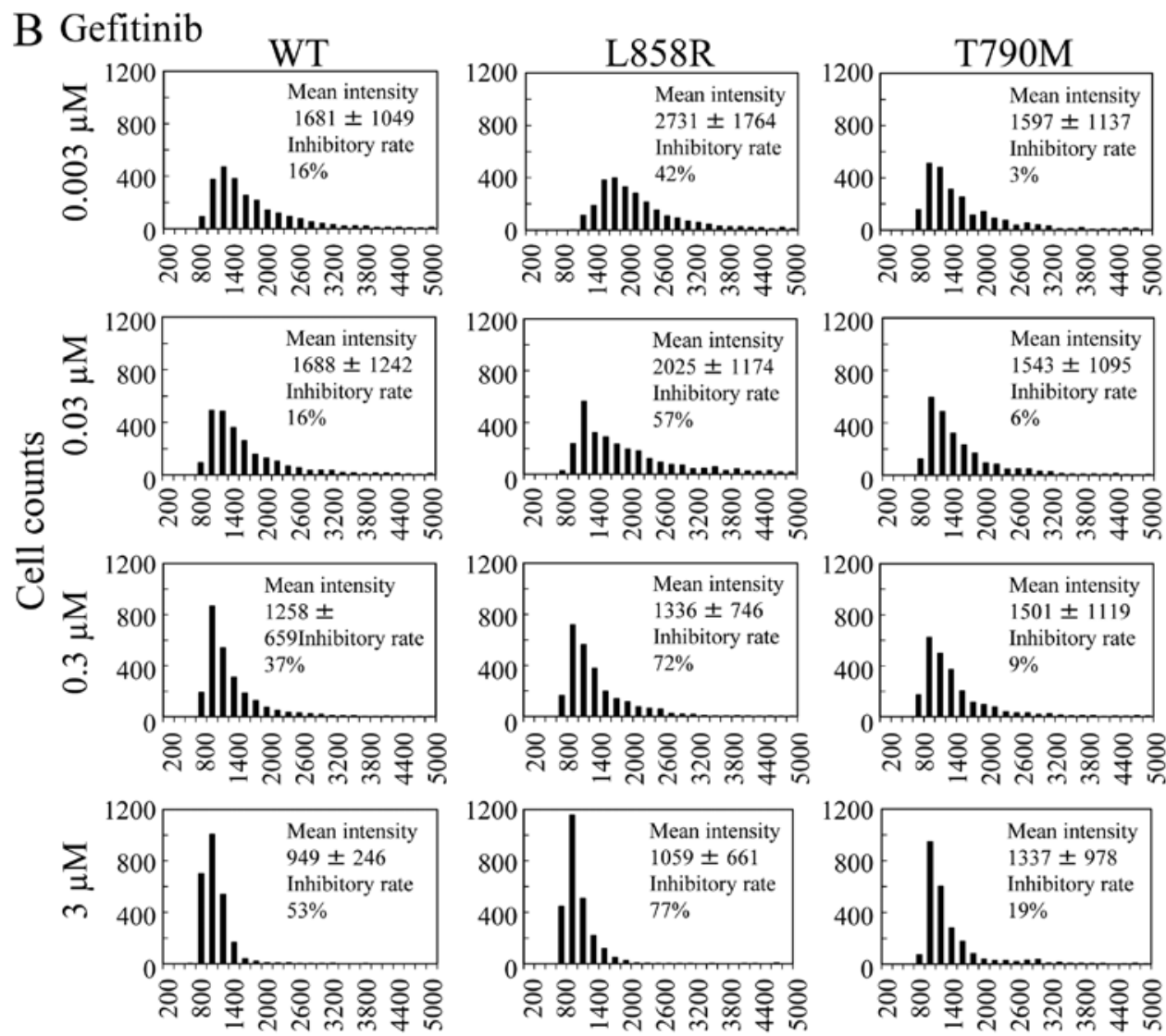

Fluorescence intensity

Figure 2. Inhibition of epidermal growth factor receptor (EGFR) phosphorylation by EGFR tyrosine kinase inhibitors (TKIs) in cells overexpressing WT, L858R and T790M EGFR. Levels of EGFR phosphorylation as measured using immunofluorescence are shown in cells treated with (A) vehicle solvent and (B) gefitinib. The fluorescence intensities of the randomly selected 2,500 cells are shown as histograms in units of 400 . The data presented are the means \pm SD $(\mathrm{n}=2,500)$. The inhibitory rate $(\%)$ is [(vehicle - EGFR TKI)/vehicle) $\mathrm{x} 100$.

the fluorescence in the isogenic cells were similar to those of the parental cells (Fig. 3A). Although the levels of EGFR in the isogenic and mutant-expressing cells were equivalent, the levels of phosphorylated EFGR in the isogenic cells were lower than those in the mutant-expressing cells. Notably, the level of phosphorylated EGFR in the constitutively active EGFR mutant L858R did not increase, unlike the observation in the L858R-expressing cells.

Next, we examined whether the growth of isogenic cells was dependent on EGF. We found that the parental (MCF 10A from Horizon Discovery) and the T790M and L858R mutant isogenic lines showed EGF dependency. In contrast to the L858R-expressing cells, the L858R mutant isogenic cells did not grow without EGF unlike the L858R-expressing cells (Fig. 3B), because the phosphorylated EGFR level in the L858R mutant isogenic cells was similar to that of the parental cells and was not elevated (Fig. 3A).

The growth inhibitory effects of 11 EGFR TKIs against parental and L858R and T790M mutant isogenic cells were tested. The $\mathrm{IC}_{50}$ values are shown in Table III. Although the EGFR TKI sensitivities against the isogenic cells were similar to those of the mutant EGFR-expressing cells, the relative ratios (mutant/WT) of the $\mathrm{IC}_{50}$ values differed. The $\mathrm{IC}_{50}$ values of gefitinib against parental, L858R and T790M isogenic cells were 218, 45 and $846 \mathrm{nM}$, respectively (Table III and Fig. 3C). The relative ratios compared to parental cells were 0.21 for L858R and 3.88 for T790M (Table III). These results showed that the drug responsiveness against isogenic mutants was 

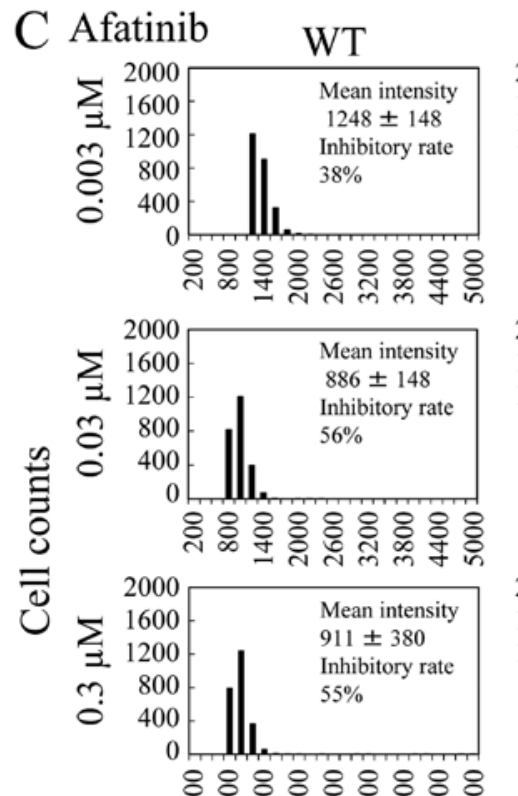

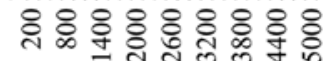

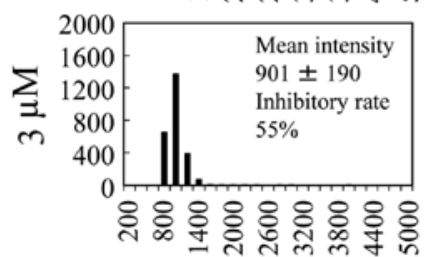

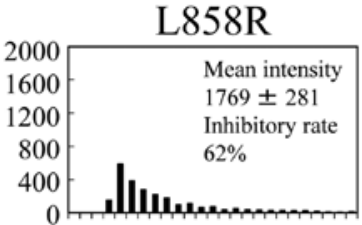

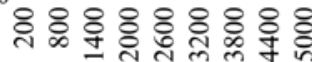

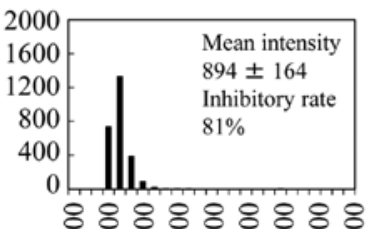

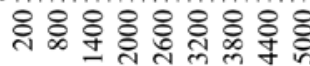

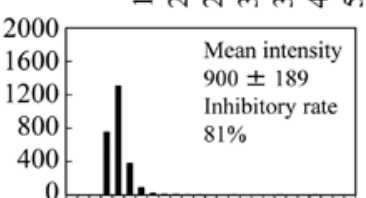

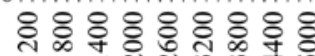

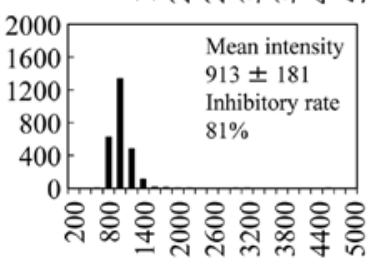

Fluorescence intensity

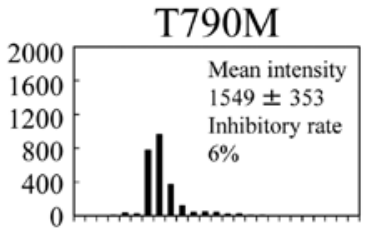

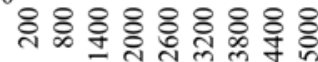

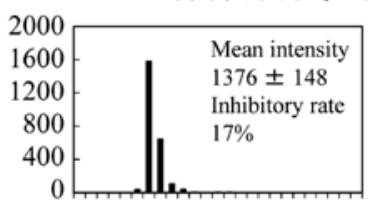

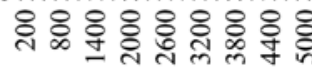

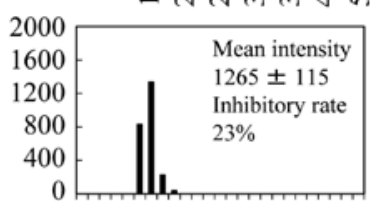

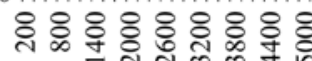

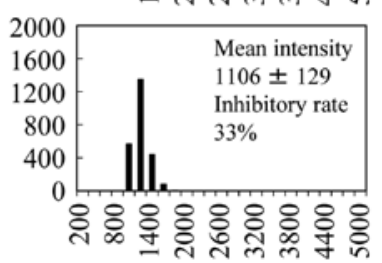

ty

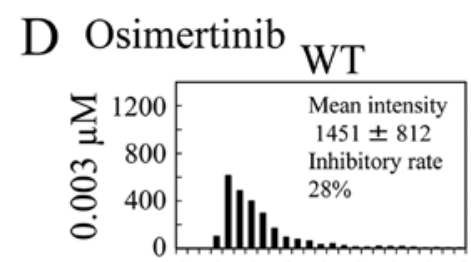

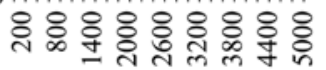
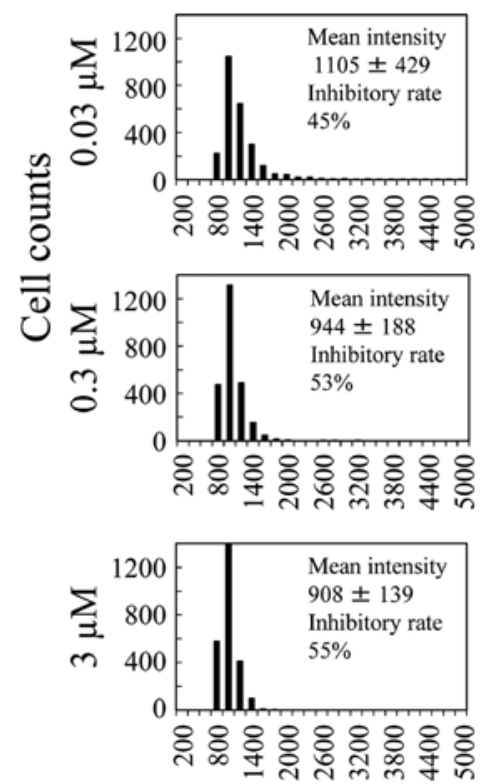

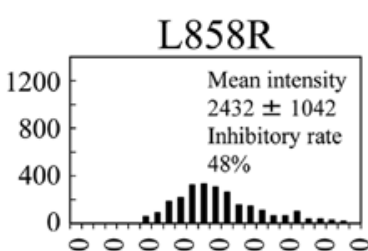

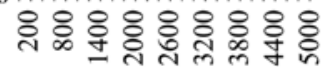
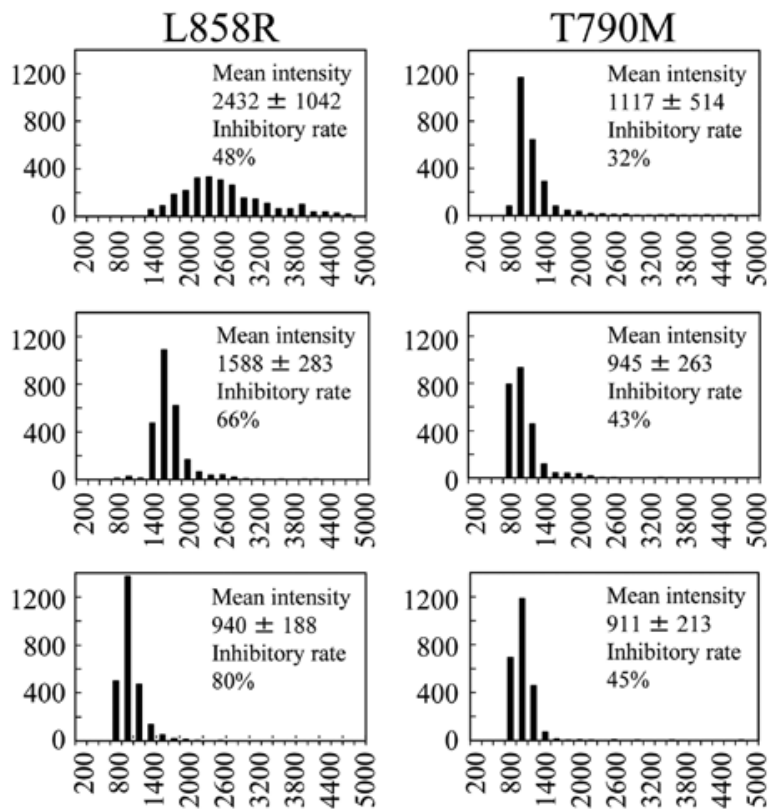

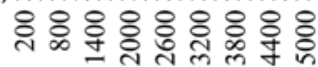
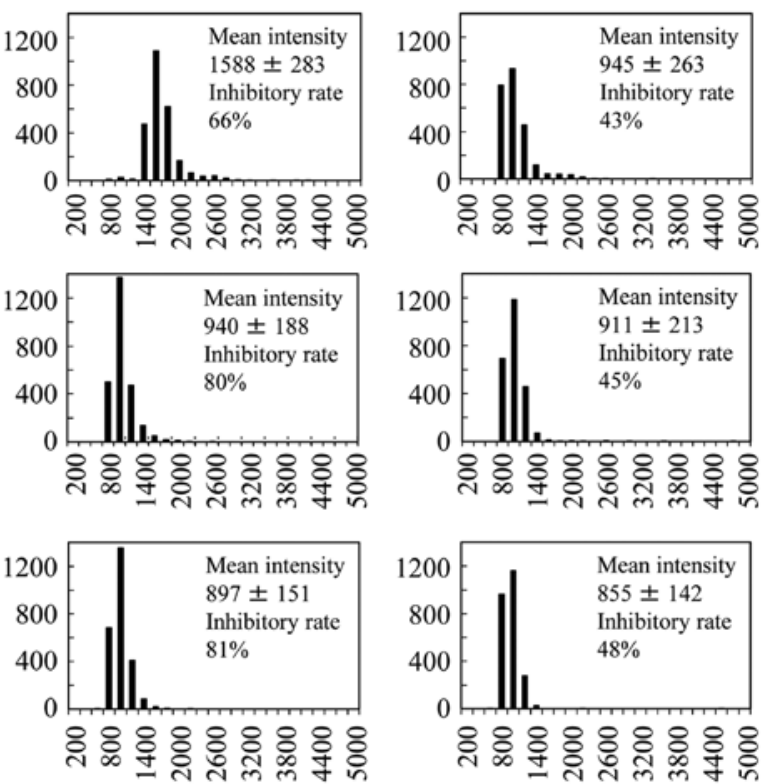

Fluorescence intensity

Figure 2. Continued. Levels of EGFR phosphorylation as measured using immunofluorescence are shown in cells treated with (C) afatinib and (D) osimertinib. The fluorescence intensities of the randomly selected 2,500 cells are shown as histograms in units of 400 . The data presented are the means \pm SD ( $=2,500$ ). The inhibitory rate (\%) is [(vehicle - EGFR TKI)/vehicle) $\mathrm{x} 100$. 
A

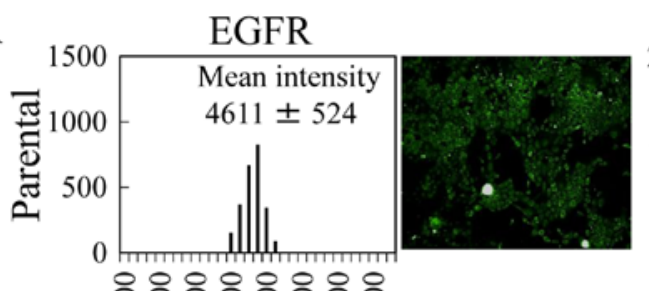

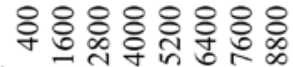

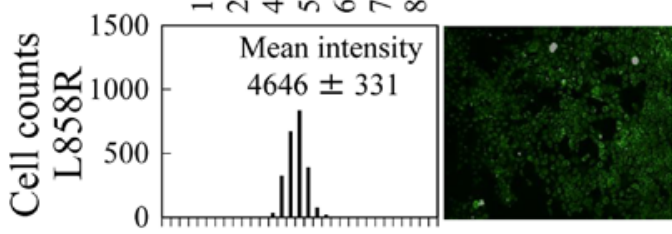

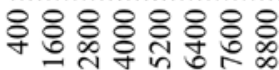

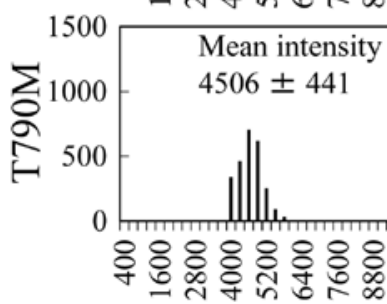

Fluorescence intensity

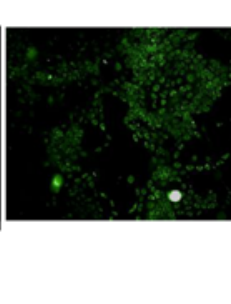

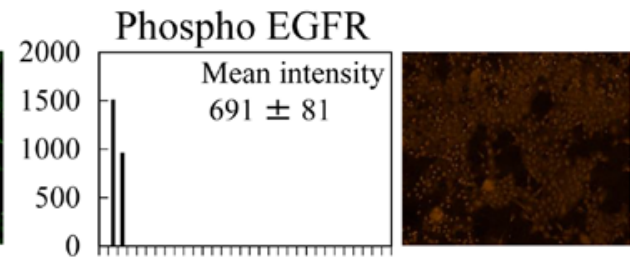

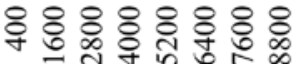

Fluorescence intensity

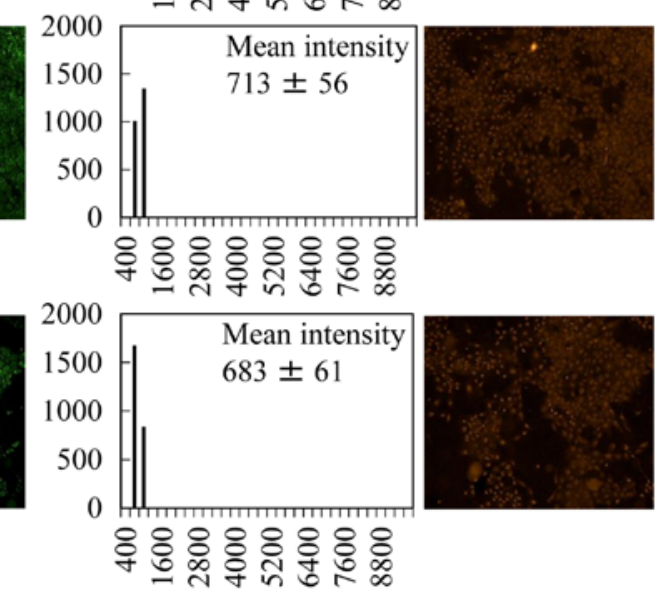

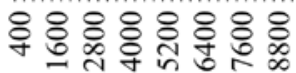

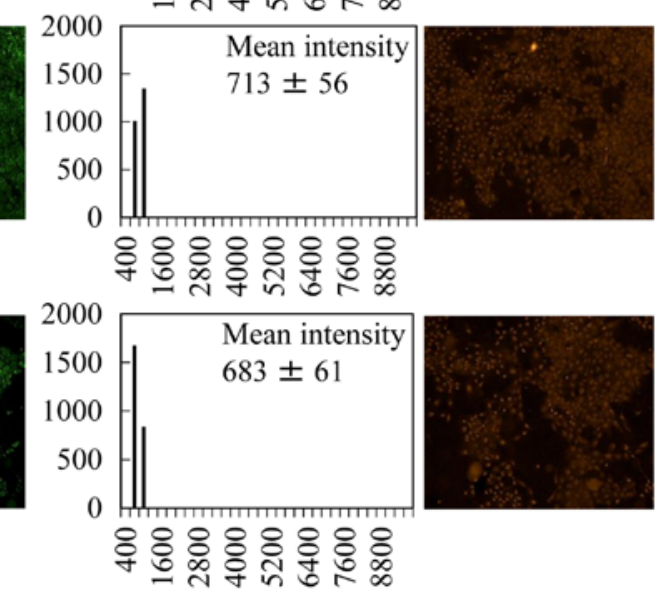

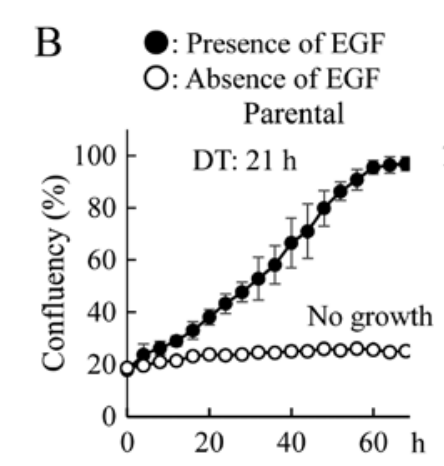
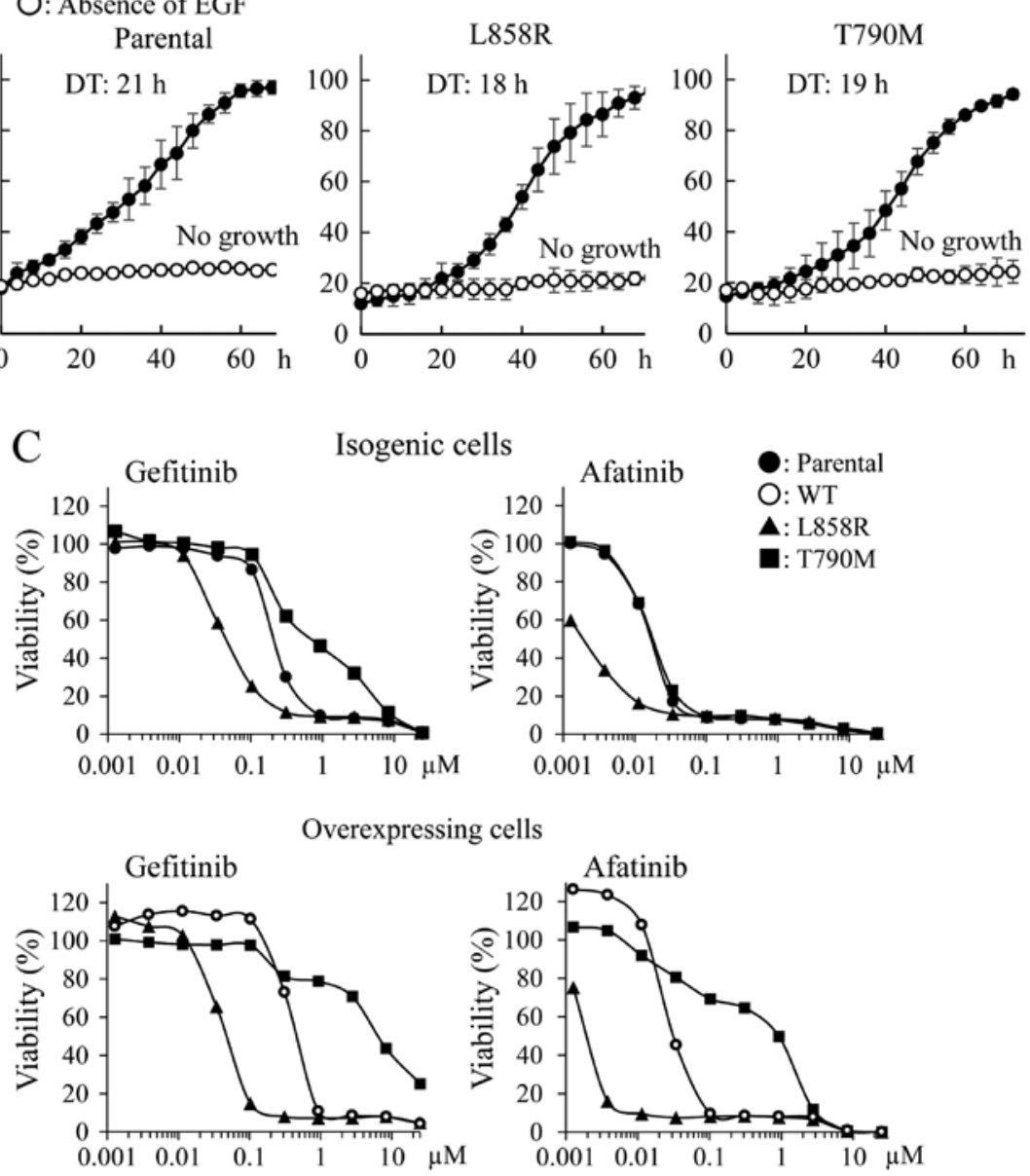

Figure 3. Comparison between the epidermal growth factor receptor (EGFR) mutation overexpressing and isogenic cells. (A) Levels of EGFR expression and its phosphorylation in isogenic cells. The fluorescence intensities of randomly selected 2,500 cells in 3 wells are shown as histograms in units of 400 . The means \pm SD $(n=2,500)$ are presented. (B) Cell growth dependency on EGF of isogenic cells with mutations in EGFR. Confluency and doubling time were measured using the IncuCyte ZOOM live cell imaging system. Doubling time (DT) represents doubling time. Each data point represents the means \pm SD $(n=9)$ of three independent experiments. (C) Effect of EGFR tyrosine kinase inhibitors (TKIs) on the proliferation of MCF 10A cells overexpressing EGFR mutant genes and of isogenic MCF 10A cells with mutations in EGFR. The data are the means of duplicate experiments. 
lower than that for mutant-expressing cells; 0.09 for L858R and 15.58 for T790M (Table II and Fig. 3C). In addition, the $\mathrm{IC}_{50}$ values of afatinib against the isogenic cells were 16 (parental), 2 (L858R), and $17 \mathrm{nM}$ (T790M), demonstrating that the parental and T790M mutant isogenic cells exhibited similar values (Table III and Fig. $3 \mathrm{C}$ ). On the contrary, the $\mathrm{IC}_{50}$ value (365 nM) of afatinib against T790M-expressing cells was higher than for cells expressing WT (28 nM) (Table II and Fig. 3C). These results indicated that our mutant gene-expressing cells may possess higher drug sensitivity than isogenic cells.

\section{Discussion}

We established MCF 10A cells overexpressing EGFR mutants to construct a novel cell-based assay for the evaluation of EGFR TKIs, which could not be correctly evaluated (i.e., in a clinically relevant manner) using available T790M-mutated tumor cell lines or xenograft models based on these cell lines (10-15) because of differences in genetic backgrounds (e.g., genome sequence and gene expression) among WT and T790M-mutated tumor cell lines. Unlike in these cell lines, the comparative analysis between WT and mutant EGFR-expressing cells is straightforward. As expected, L858R-expressing cells showed an increase of EGFR TKI sensitivity compared with cells expressing WT, whereas T790M-expressing cells showed resistance against EGFR TKIs (Table II). In addition, the third generation of EGFR TKIs inhibited the cell growth of T790M-expressing cells that were more resistant to the first and second generation than were WT. For example, the third-generation agent osimertinib (currently marketed) exhibited substantially higher inhibitory activity against the cell growth of T790M-expressing cells than erlotinib and gefitinib. These results were identical with the clinical findings for these drugs $(1,7)$, suggesting the possibility of evaluation reflecting the state of cancer tissue in an organism using this mutant-expressing cell line. Furthermore, our results suggest the additional possibility of the utility of this mutant EGFR-expressing line for the evaluation of mutant-selective inhibitors and drug screening.

The isogenic cell line technology used to develop the lines studied here was initially developed by Di Nicolantonio et al, wherein a panel of isogenic human cell lines was created by employing homologous recombination (27). The isogenic cells (T790M and L858R mutants) exhibited sensitivity toward EGFR TKIs as expected; however, our mutant gene-expressing cells exhibited higher drug sensitivity than these isogenic cells (Fig. 3C). In addition, L858R mutant isogenic cells did not show growth in medium without EGF (Fig. 3B). We consider that the difference in drug sensitivity and cell growth is due to the levels of mutant EGFR and of EGFR phosphorylation, as the EGFR mutant gene-expressing cells showed higher levels of EGFR expression and phosphorylation than the control line (Fig. 1), whereas mutant isogenic cell EGFR expression was equivalent to the parental line and phosphorylated EGFR did not accumulate (Fig. 3).

In conclusion, the results of this study demonstrate that our mutant gene-expressing cell model is superior to isogenic cells for the evaluation of anti-EGFR drug efficacy against EGFR mutation.

\section{Acknowledgements}

This study was partially supported by grants for translational research programs from Fukushima Prefecture.

\section{References}

1. Russo A, Franchina T, Ricciardi GR, Picone A, Ferraro G, Zanghì M, Toscano G, Giordano A and Adamo V: A decade of EGFR inhibition in EGFR-mutated non small cell lung cancer (NSCLC): Old successes and future perspectives. Oncotarget 6: 26814-26825, 2015.

2. Gazdar AF: Activating and resistance mutations of EGFR in non-small-cell lung cancer: Role in clinical response to EGFR tyrosine kinase inhibitors. Oncogene 28 (Suppl 1): S24-S31, 2009.

3. Siegel R, Naishadham D and Jemal A: Cancer statistics, 2013. CA Cancer J Clin 63: 11-30, 2013.

4. Moran C: Importance of molecular features of non-small cell lung cancer for choice of treatment. Am J Pathol 178: 1940-1948, 2011.

5. Paez JG, Jänne PA, Lee JC, Tracy S, Greulich H, Gabriel S, Herman P, Kaye FJ, Lindeman N, Boggon TJ, et al: EGFR mutations in lung cancer: Correlation with clinical response to gefitinib therapy. Science 304: 1497-1500, 2004.

6. Lynch TJ, Bell DW, Sordella R, Gurubhagavatula S, Okimoto RA, Brannigan BW, Harris PL, Haserlat SM, Supko JG, Haluska FG, et al: Activating mutations in the epidermal growth factor receptor underlying responsiveness of non-small-cell lung cancer to gefitinib. N Engl J Med 350: 2129-2139, 2004.

7. Massarelli E, Johnson FM, Erickson HS, Wistuba II and Papadimitrakopoulou V: Uncommon epidermal growth factor receptor mutations in non-small cell lung cancer and their mechanisms of EGFR tyrosine kinase inhibitors sensitivity and resistance. Lung Cancer 80: 235-241, 2013.

8. Keedy VL, Temin S, Somerfield MR, Beasley MB, Johnson DH, McShane LM, Milton DT, Strawn JR, Wakelee HA and Giaccone G: American Society of Clinical Oncology provisional clinical opinion: Epidermal growth factor receptor (EGFR) Mutation testing for patients with advanced non-small-cell lung cancer considering first-line EGFR tyrosine kinase inhibitor therapy. J Clin Oncol 29: 2121-2127, 2011.

9. Stinchcombe TE: Novel agents in development for advanced non-small cell lung cancer. Ther Adv Med Oncol 6: 240-253, 2014.

10. Kwak EL, Sordella R, Bell DW, Godin-Heymann N, Okimoto RA, Brannigan BW, Harris PL, Driscoll DR, Fidias P, Lynch TJ, et al: Irreversible inhibitors of the EGF receptor may circumvent acquired resistance to gefitinib. Proc Natl Acad Sci USA 102: 7665-7670, 2005.

11. Engelman JA, Zejnullahu K, Gale CM, Lifshits E, Gonzales AJ, Shimamura T, Zhao F, Vincent PW, Naumov GN, Bradner JE, et al: PF00299804, an irreversible pan-ERBB inhibitor, is effective in lung cancer models with EGFR and ERBB2 mutations that are resistant to gefitinib. Cancer Res 67: 11924-11932, 2007.

12. Li D, Ambrogio L, Shimamura T, Kubo S, Takahashi M, Chirieac LR, Padera RF, Shapiro GI, Baum A, Himmelsbach F, et al: BIBW2992, an irreversible EGFR/HER2 inhibitor highly effective in preclinical lung cancer models. Oncogene 27: 4702-4711, 2008.

13. Miller VA, Hirsh V, Cadranel J, Chen YM, Park K, Kim SW, Zhou C, Su WC, Wang M, Sun Y, et al: Afatinib versus placebo for patients with advanced, metastatic non-small-cell lung cancer after failure of erlotinib, gefitinib, or both, and one or two lines of chemotherapy (LUX-Lung 1): A phase $2 \mathrm{~b} / 3$ randomised trial. Lancet Oncol 13: 528-538, 2012.

14. Sequist LV, Besse B, Lynch TJ, Miller VA, Wong KK, Gitlitz B, Eaton K, Zacharchuk C, Freyman A, Powell C, et al: Neratinib, an irreversible pan-ErbB receptor tyrosine kinase inhibitor: Results of a phase II trial in patients with advanced non-small-cell lung cancer. J Clin Oncol 28: 3076-3083, 2010.

15. Reckamp KL, Giaccone G, Camidge DR, Gadgeel SM, Khuri FR, Engelman JA, Koczywas M, Rajan A, Campbell AK, Gernhardt D, et al: A phase 2 trial of dacomitinib (PF-00299804), an oral, irreversible pan-HER (human epidermal growth factor receptor) inhibitor, in patients with advanced non-small cell lung cancer after failure of prior chemotherapy and erlotinib. Cancer 120: 1145-1154, 2014. 
16. Walter AO, Sjin RT, Haringsma HJ, Ohashi K, Sun J, Lee K, Dubrovskiy A, Labenski M, Zhu Z, Wang Z, et al: Discovery of a mutant-selective covalent inhibitor of EGFR that overcomes T790M-mediated resistance in NSCLC. Cancer Discov 3: 1404-1415, 2013.

17. Sequist LV, Soria JC, Goldman JW, Wakelee HA, Gadgeel SM, Varga A, Papadimitrakopoulou V, Solomon BJ, Oxnard GR, Dziadziuszko R, et al: Rociletinib in EGFR-mutated non-small-cell lung cancer. N Engl J Med 372: 1700-1709, 2015.

18. Cross DA, Ashton SE, Ghiorghiu S, Eberlein C, Nebhan CA, Spitzler PJ, Orme JP, Finlay MR, Ward RA, Mellor MJ, et al: AZD9291, an irreversible EGFR TKI, overcomes T790M-mediated resistance to EGFR inhibitors in lung cancer. Cancer Discov 4: 1046-1061, 2014.

19. Jänne PA, Yang JC, Kim DW, Planchard D, Ohe Y, Ramalingam SS, Ahn MJ, Kim SW, Su WC, Horn L, et al: AZD9291 in EGFR inhibitor-resistant non-small-cell lung cancer. N Engl J Med 372: 1689-1699, 2015.

20. Gendreau SB, Ventura R, Keast P, Laird AD, Yakes FM, Zhang W, Bentzien F, Cancilla B, Lutman J, Chu F, et al: Inhibition of the T790M gatekeeper mutant of the epidermal growth factor receptor by EXEL-7647. Clin Cancer Res 13: 3713-3723, 2007.

21. Somwar R, Shum D, Djaballah H and Varmus H: Identification and preliminary characterization of novel small molecules that inhibit growth of human lung adenocarcinoma cells. J Biomol Screen 14: 1176-1184, 2009.

22. Wang HY, Hsu MK, Wang KH, Tseng CP, Chen FC and Hsu JT: Non-small-cell lung cancer cells combat epidermal growth factor receptor tyrosine kinase inhibition through immediate adhesion-related responses. Onco Targets Ther 9: 2961-2973, 2016.
23. Greulich H, Chen TH, Feng W, Jänne PA, Alvarez JV, Zappaterra M, Bulmer SE, Frank DA, Hahn WC, Sellers WR, et al: Oncogenic transformation by inhibitor-sensitive and -resistant EGFR mutants. PLoS Med 2: e313, 2005.

24. Carey KD, Garton AJ, Romero MS, Kahler J, Thomson S, Ross S, Park F, Haley JD, Gibson N and Sliwkowski MX: Kinetic analysis of epidermal growth factor receptor somatic mutant proteins shows increased sensitivity to the epidermal growth factor receptor tyrosine kinase inhibitor, erlotinib. Cancer Res 66: 8163-8171, 2006.

25. Lin WH, Song JS, Lien TW, Chang CY, Wu SH, Huang YW, Chang TY, Fang MY, Yen KJ, Chen CH, et al: A high-throughput cell-based screening for L858R/T790M mutant epidermal growth factor receptor inhibitors. Anticancer Res 32: 147-151, 2012.

26. Goshima N, Kawamura Y, Fukumoto A, Miura A, Honma R, Satoh R, Wakamatsu A, Yamamoto J, Kimura K, Nishikawa T, et al: Human protein factory for converting the transcriptome into an in vitro-expressed proteome. Nat Methods 5: 1011-1017, 2008.

27. Di Nicolantonio F, Arena S, Gallicchio M and Bardelli A: Isogenic mutant human cells: A new tool for personalized cancer medicine. Cell Cycle 9: 20-21, 2010 